\title{
PROCESSED ANIMAL PROTEIN AS ONE OF THE ELEMENTS OF THE POLICY FOR REDUCING GMOS IN THE FEEDING OF LIVESTOCK
}

\author{
WIESEAW DZWONKOWSKI
}

\begin{abstract}
The aim of this article is to present various conditions and aspects of the use of processed animal protein (PAP) in the feeding of livestock in the perspective of lifting the 20-year ban on its use in feed and determining its role in the policy of reducing GMOs.

The study analyzes the current legal status, as well as new conditions and requirements at each production stage, with the management of processed animal protein based on the relevant Polish and EU legal acts. It also determines the scale of production and directions of the current PAP management, as well as the price conditions of its potential use in feed production. In the analysis, in addition to the literature on the subject, the authors used mainly source data from the Chief Veterinary Inspectorate, Statistics Poland, and the Ministry of Finance.

The analysis of organizational and production conditions led to the conclusion that the main problem may be to maintain the so-called species purity in the production of PAP and feed with its use, followed by cross-feeding (PAP from poultry in pig feed and PAP from pigs in poultry feed), and severe consequences in the event of detecting irregularities. Moreover, a limiting factor may be the high price in relation to other protein feeds and consumer expectations that the animal products offered for sale were produced without the use of animal feed. The role and importance of processed animal protein approved for feeding in the balance of high-protein feed raw materials is likely to be small, but every possibility of using domestic protein sources should be encouraged and exploited to reduce the use of imported GM feed and improve protein self-
\end{abstract}

Wiesław Dzwonkowski, MSc, Institute of Agricultural and Food Economics - National Research Institute, Department of Agricultural Markets and Quantitative Methods; ul. Świętokrzyska 20, 00-002 Warsaw, Poland (Wieslaw.Dzwonkowski@ierigz.waw.pl). ORCID iD: 0000-0002-8996-1419. 
-sufficiency. However, a larger scale of domestic use of this very valuable source of protein may require administrative action by introducing indicative targets for the substitution of imported GM feed with domestic protein sources.

Keywords: substitution, processed animal protein, GMO feed, cross-feeding.

JEL codes: Q01, Q13, Q18.

\section{Introduction}

For many years, the subject of discussion and research has been the possibility of an increased use of native protein raw materials to replace, or at least supplement, imported genetically modified post-extraction soybean meal, which in approx. 60\% constitutes the resources of high-protein feed raw materials used in Poland (Rutkowski, 2020). Vegetable protein is considered and analyzed as alternative feed (Grela and Czech, 2019). There has also been an ongoing discussion in other European Union countries, whether and to what extent the use of feed with GMOs, especially soybean, can be eliminated from animal nutrition (Davison and Ammann, 2017), paying little attention to proteins of animal origin, due to the still binding ban on their use in the feeding of livestock.

In the context of the GMP + FSA international feed certification scheme, processed animal protein (PAP) is a type of protein that has been processed in such a way as to make it suitable for direct use as feed or as a feed material to produce feed for animals (Gmplus.org, 2021). It includes fishmeal, PAP from poultry, pigs, ruminants, and mixed PAP, PAP derived from processing horns, hooves, blood, feathers, including compound feed containing these products. According to the definition specified in Commission Regulation (EU) No. 142/2011 of 25 February 2011, "processed animal protein means animal protein derived entirely from Category 3 material, which has been treated in accordance with Section 1 of Chapter II of Annex X (including blood meal and fishmeal) so as to render them for direct use as feed material or for any other use in feedingstuffs, including petfood, or for use in organic fertilisers or soil improvers; however, it does not include blood products, milk, milk-based products, milk-derived products, colostrum, colostrum products, centrifuge or separator sludge, gelatin, hydrolysed proteins or dicalcium phosphate, eggs and egg- products including egg shells, phosphate tricalcium and collagen" (Regional Inspectorate..., 2021). Chapter II, Section 1 of that regulation (142/2011) includes specific requirements for processed animal protein.

Modern technologies of feeding animals require that the feed used contain an appropriate level of complete protein, which determines the appropriate health condition and weight gain. The quality of feed is of fundamental importance in animal nutrition, especially the quantity and quality of protein it contains (Buraczewska and Buraczewski, 2015). This applies in particular to high-intensity rearing and modern feeding technologies which require the use of properly balanced compound feed. 
The use of processed animal protein (except fishmeal) for feeding livestock in EU countries is still prohibited (the so-called feed ban). In the European Union, the ban on the use of animal meal in feeding animals was introduced in 2001 due to the connection between mad cow disease (BSE) with the use of this protein raw material to produce feed. On the other hand, in Poland (which at that time was not a member of the EU), a complete ban on the use of meat and bone meals in the feeding of livestock was introduced on November 1, 2003. Since then, the issue of lifting the ban on animal meals and using them as feed has been raised many times. Currently, fish meal is an exception and can be used in feed for pigs, poultry, and for calves as a component of milk replacers. Moreover, processed animal proteins other than fish meal, derived from non-ruminants, may be used in the feeding of aquaculture animals.

Recently, however, there have been serious reasons that it will probably be possible to feed animals with protein from the processing (utilization) of animal by-products as early as 2021. On 7-9 April 2021, a written vote was held by EU Member States on the draft amendment to Annex IV to Regulation (EC) No. 999/2001 of the European Parliament and of the Council. 26 countries voted in favor of the draft amendment, with one abstention (France). The voted changes concern partial admission of processed animal protein in the so-called cross-feeding. The draft approved by the European Commission was submitted for proceedings in the European Parliament and the European Commission. The planned publication in the EU Official Journal is scheduled for the beginning of October 2021 with the entry into force 20 days after its publication, which will put an end to the long-term battle to restore the use of processed animal protein in livestock feed. According to the changes proposed by the European Commission, the so-called "cross-use" of processed animal proteins in the feeding of pigs and poultry will be allowed. This means that it will be possible to use PAP produced from poultry by-products in feed for pigs and PAP derived from pig by-products will be allowed in feed for poultry. The planned legislative changes are expected by the feed industry and the animal production sector. Before the introduction of the feed ban in Poland (2003), most of the proteins produced of animal origin were used in feeding livestock. In addition to the literature on the subject, the analysis uses first source data (unpublished) from the Chief Inspectorate of Veterinary Medicine, the Ministry of Finance, and Statistics Poland (GUS, 2011-2020).

\section{Organizational and production conditions}

To present the essence of the proposed changes and the resulting possibilities, it is necessary to analyze the conditions, the scale of production, and the current management of processed animal protein. The starting point is the raw material from which processed animal protein is obtained, i.e., animal by-products (the so-called ABPs), which are any material of animal origin that is not intended for human consumption. The main source of ABPs are enterprises of the food sector producing food of animal origin (slaughterhouses, cutting plants, meat processing 
plants) and farms keeping livestock. Retail stores are an additional source of ABPs, which generate products of animal origin after the expiry date or products with damaged packaging, together with restaurants and catering activities generating the so-called catering waste and farms breeding carnivorous fur animals, where hides/skins and carcasses of carnivorous fur animals are produced, as a result of the skinning process of animals. The transport industry of goods and people, which generates a certain part of ABPs, in the form of the so-called waste from international transport (third countries - EU) and internal transport (EU - EU), is also of some significance.

Animal by-products (ABPs) are divided into three categories depending on the risks they pose (detailed rules of categorization and management are set out in the provisions of Regulation (EC) No. 1069/2009 of the European Parliament and of the Council and Commission Regulation (EU) No. 142/2011). ABPs from Category 1 belong to the special risk group (showing the risk associated with prions, the use of prohibited substances or environmental contaminants). They are, among others: carcasses and all parts of the body of animals suspected of being infected with TSE - transmissible spongiform encephalopathies, carcasses of wild animals suspected of being infected with a disease communicated to humans or animals, specific SRM hazardous material (parts of the body that pose a particular risk of prion disease, e.g., spinal cord, bovine brain) and fallen livestock containing SRM material (upon disposal). ABPs from Category 2 included in the high-risk group (showing a microbiological risk or the risk related to the presence of substances or contaminants in amounts exceeding the acceptable levels) include, among others: fallen livestock (e.g., pigs, poultry, equines), parts of the body of animals obtained during slaughter showing signs of disease, carcasses containing residues of chemical substances (e.g., veterinary medicinal products). On the other hand, ABPs from Category 3, from which processed animal protein (PAP) is derived according to the EU nomenclature, belong to the low-risk group. They are:

- carcasses or body parts of animals slaughtered in a slaughterhouse for human consumption;

- products or food of animal origin originally intended for human consumption but withdrawn for commercial reasons;

- catering waste;

- shells from shellfish with soft tissue;

- eggs, egg by-products, hatchery by-products, and egg shells;

- aquatic animals, aquatic and terrestrial invertebrates;

- hides and skins from slaughterhouses;

- animal hides, skins, hooves, feathers, wool, horns, and hair, derived from animals that showed no signs of contagious disease at the time of slaughter.

The categorization depends on the level of risk posed by ABPs and leads to a different management of ABPs, from destruction to use in the feed, technical, or pharmaceutical industries. 
ABPs from Category 3 are managed through processing in processing plants and being used as feed materials to produce feed for livestock (in accordance with the rules of the still binding feed ban), as well as their processing and use to produce pet food. In the structure of unprocessed ABPs produced in Poland in 2020 in terms of the main groups (entities) of their use, $78.6 \%$ were processing plants, $13.5 \%$ fur breeders, and $7.9 \%$ pet food producers (Mroczek and Dzwonkowski, 2021).

Defining derivative products resulting from ABPs is a very important issue. ABPs from Categories 1 and 2 are used to produce meat and bone meal, and processed animal protein, i.e., processed animal meal, is produced from ABPs from Category 3. According to the currently valid legal nomenclature, it means that meat and bone meals will not be allowed for feeding, because they are produced from ABPs from Category 1 and 2, i.e., with a special and high risk, which, except for a few derogations, eliminates the possibility of their use for feed purposes. Only processed animal protein (PAP), which is derived in the processing of low-risk by-products from Category 3, will be allowed to use to a limited extent as a feed material. The adopted draft amendments to the feed ban also provide for the approval of feeding poultry and pigs with processed animal protein from insects and for the use of collagen and gelatin derived from ruminants for the feeding of livestock other than ruminants.

The planned approval of PAP feeding in livestock rearing is possible, because the PCR (polymerase chain reaction) method developed by EURL-AP (European Union Reference Laboratory for Animal Proteins) allows the detection of DNA from poultry and pigs, which will enable controlling and monitoring compliance with the strict rules of processing and cross-feeding of this protein (Weiner, $\mathrm{Pa}$ procka, Gołębiowska and Kwiatek, 2016; 2018). It is a qualitative method, not a quantitative one, which will allow to determine the contamination of DNA with unwanted protein but will not determine its scale in the tested material. In addition, another important aspect is the so-called Green Deal, i.e., the policy of the so-called Green Deal (European Green Deal), which consists in creating legal possibilities for the most effective use of generated resources and limiting the negative impact on the environment. This policy includes the widest possible use of animal proteins resulting from the ABPs already generated for feeding animals.

The use of PAP in the feeding of livestock (cross-feeding of pigs and poultry) will be associated with the observance of very stringent requirements in the entire production and marketing chain, ranging from regulations on source plants, where ABPs are derived, transport to processing plants, through the production of PAP in a processing plant, transport to a feed plant, where PAP will be used for the production of mixtures and concentrates, to the control of the transport process, storage, and feeding with PAP on a farm, or on a pig or poultry farm. Throughout this chain, "species purity" must be preserved. Thus, to produce processed poultry protein it will be possible to use ABPs only from slaughterhouses, cutting plants, other plants handling poultry material, registered by district veterinarians as plants not slaughtering and cutting ruminants and pigs (in accordance with Article R 853/2004) and non-using pig and ruminant material. Derogations (conditional derogations) from 
the rules will be possible, as district veterinarians will be able to authorize source and poultry plants simultaneously slaughtering, cutting or handling and storing materials from ruminants and pigs only if, during the inspection, the veterinarian finds that at each stage in the plant there is a physical separation between poultry material and other materials, the plant has a system of regular sampling of Category 3 raw material for quality testing, in accordance with a frequency based on a risk analysis, and the plant has written procedures in place for the activities mentioned above in the HACCP plan.

Transporting poultry by-products from Category 3 intended to produce PAP from poultry from source plants will be possible by means of transport and containers that are not used to transport ABPs from ruminants and pigs. Derogations may also be applied here provided that the vehicles and containers have been previously cleaned to avoid cross-contamination in accordance with a documented procedure previously authorized by the district veterinarian.

The production of PAP from poultry will only be allowed in a plant intended for the processing of poultry PAP from source plants, registered by a competent authority as not intended for processing PAP from ruminants or pigs. However, also in this case, there may be some conditional derogations if the plant implements preventive measures:

- the production of PAP from ruminants and pigs must take place in a closed system that is physically separated from that used to produce PAP from poultry;

- separate storage and transport of ABPs from poultry and other species;

- separate packing and storage of PAP from poultry and other species;

- regular PAP sampling for laboratory analysis entered in the HACCP (specified frequency, storage of results for a period of 5 years).

Also, transporting the produced PAP from poultry intended for the production of feed for pigs can be carried out according to the same strict rules as Category 3 ABPs used for its production, with conditional derogation as in the case of the previously discussed procedures. The above procedures are similar in the acquisition, production, and transport of PAP from pigs intended for poultry.

In feed plants producing feed from PAP, it will not be possible to produce feed for different species of livestock on one production line. This means that there must be a physical separation and there must be dedicated production lines to produce feed for poultry and pigs. The condition of complete physical separation applies not only to the production stage, but also to the storage and transport of compound feed. There will also be no possibility of producing the above-mentioned types of feeds on the same technological line with separation in time (e.g., one week for the production of feed for poultry, and the next one for pigs; this will be prohibited in the case of feed production from PAP).

To ensure the production of PAP from poultry or/and pigs, it will be necessary to establish an "interlocking" chain of "species purity" and control it at various stages: 
- slaughterhouses, cutting plants, other approved plants (Article 4 of Regulation $853 / 2004$ ) and intermediate plants;

- processing plants (production of PAP);

- plants producing compound feed with the participation of PAP;

- storage and transport of feed containing PAP;

- feeding on the farm.

As can be seen from the above, a short overview of production conditions, the implementation of the feeding of PAP from poultry to pigs and PAP from pigs to poultry will face major challenges, both for the participants of this chain and the relevant control services. In the event of possible contamination, it may be difficult to identify the stage at which it has taken place. The scale and scope of the requirements to be met so that pure pig and poultry PAP began to be produced on a larger scale and then used in feed with the entry into force of the relevant regulations may constitute a significant threshold of difficulty. Moreover, the prepared legal regulations state that if there is a confirmed suspicion that illegal animal by-products or derived products have been used in the feeding of livestock, the district veterinarian orders to kill such animals by way of a decision. This may be a significant factor which makes end-users skeptical about the use of feeds containing PAP in their formulas.

\section{Supply, demand, and price conditions for the use of PAP in feed production and feeding livestock}

Processed animal protein can only be produced from Category 3 animal by-products. The largest amounts of Category 3 "raw materials" processed by the rendering sector in Poland are animal by-products (ABPs) from slaughterhouses and abattoirs. The volume of their processing between 2012 and 2020, divided into categories, is presented in Table 1 . The amount is primarily a derivative of the volume of livestock production and industrial slaughter of animals for slaughter.

Animal by-products accepted into processing plants by category (thousand tonnes)

Table 1

\begin{tabular}{lrrrrrrrrr}
\hline \multirow{2}{*}{$\begin{array}{l}\text { Material } \\
\text { category }\end{array}$} & \multicolumn{10}{c}{ Years } \\
\cline { 2 - 10 } & 2012 & 2013 & 2014 & 2015 & 2016 & 2017 & 2018 & 2019 & 2020 \\
\hline Total & $1,095.5$ & $1,068.4$ & $1,258.7$ & $1,406.8$ & $1,520.5$ & $1,625.6$ & $1,673.4$ & $1,777.2$ & $1,872.5$ \\
Category 1 & 259.2 & 246.1 & 272.5 & 280.3 & 272.9 & 281.3 & 286.2 & 286.9 & 289.6 \\
Category 2 & 81.0 & 82.0 & 68.4 & 41.5 & 37.6 & 27.9 & 11.7 & 8.7 & 10.0 \\
Category 3 & 755.3 & 740.3 & 917.7 & 1085.1 & $1,210.1$ & $1,316.3$ & $1,375.6$ & $1,481.6$ & $1,572.9$ \\
$\begin{array}{l}\text { Share \% } \\
\text { of Category 3 }\end{array}$ & 68.9 & 69.3 & 72.9 & 77.1 & 79.6 & 81.0 & 82.2 & 83.4 & 84.0 \\
\hline
\end{tabular}

Source: unpublished data from the Chief Veterinary Inspectorate. 
From 2010-2020, the production of live pigs slightly decreased (from 2,388 to 2,376 thousand tonnes), whereas the production of beef and veal increased by $37 \%$ to 1,100 thousand tonnes. The production of poultry livestock was characterized by the fastest dynamics and the greatest increase from 1,971 to 3,749 thousand tonnes (an increase by $90 \%$, with an average annual rate of 6.6\%) (Figure 1). Along with the increased productionof livestock, especially poultry, the amount of ABPs also increased, mainly in Category 3.

The Chief Veterinary Inspectorate, which is practically the only source of information on the processing of ABPs and the amounts of products derived from this process, does not collect statistics that distinguish the species origin of Category 3 source material, nor does it distinguish between the types of PAP produced for poultry or pork. However, considering the dominant share of poultry livestock production, it can be assumed that in the structure of PAP produced so far, the share of poultry protein is greater than that of pork. However, such a conclusion can be reached by analyzing the volume of livestock production from slaughterhouses and abattoirs and by assuming appropriate indicators to calculate the amounts of by-products intended for disposal (i.e., processing for PAP). The indices were defined as differences between the post-slaughter capacity indexes (according to the Statistics Poland nomenclature) and unity, i.e., if the total poultry post-slaughter capacity index is $75 \%$, then the index for calculating the amount of ABPs was assumed to be $25 \%$, whereas for pigs 78 and 22\%, respectively (Mroczek and Dzwonkowski, 2021). On the basis of relevant statistics and calculations, it was established that from 2017-2019 the potential amount of ABPs from poultry was 828, 876 and 887 thousand tonnes, and from pigs 578, 606 and 568 thousand tonnes, respectively. In 2019 , poultry by-products constituted approx. $60 \%$ of the structure and pork by-products approx. 40\%. Rendering plants do not have to provide "species purity" and most often produce mixed PAP, but necessarily from Category 3 raw material. They find buyers for PAP produced in this way without any problems. It should be noted that slaughterhouses and abattoirs are not the only, but the dominant source of raw material, as mentioned earlier. 


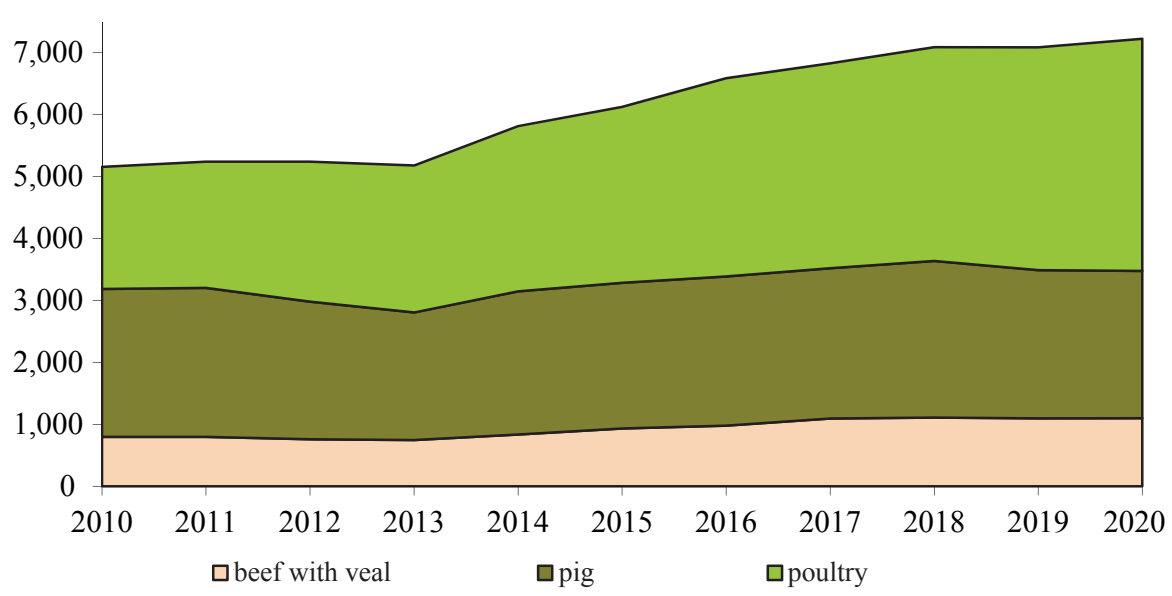

Fig. 1. Production of poultry, pig, and beef livestock in Poland from 2010-2020.

Source: authors' own study based on Statistics Poland, 2011-2020; Rynek mięsa..., 2021.

In 2020, approx. 75 thousand tonnes of meat and bone meal and approx. 25 thousand tonnes of fats were produced from Category 1 animal by-products (including fallen animals - ruminants, domestic animals). Category 2 ABPs, which are not numerous, were used to produce 1.2 thousand tonnes of meals and 2.1 thousand tonnes of fats. Products made of Category 1 and 2 materials cannot and will not be allowed to use in the feeding of livestock, and after the ban is lifted, only those made of Category 3 material will be permitted ${ }^{1}$. According to unpublished data of the General Veterinary Inspectorate, the amount of processed Category 3 material from 2017-2020 increased from approx. 1,316 to 1,573 thousand tonnes, i.e., by less than $20 \%$. The main two products derived from this raw material are processed animal protein, the production of which in the last four years increased by $16 \%$ from 295.8 to 343.2 thousand tonnes and fat which increased by $26 \%$ in this period (from 177.3 to 223.7 thousand tonnes).

\footnotetext{
${ }^{1}$ In Regulation (EC) No. 1069/2009 of the European Parliament and of the Council, Article 18 includes Category 2 material (provided that it comes from animals which were not killed or did not die as a result of the presence or suspected presence of a disease communicable to humans or animals) for feeding to zoo animals, circus animals, reptiles and birds of prey other than zoo or circus animals, fur animals, wild animals, dogs from recognized kennels or packs of hounds, dogs and cats in shelters, maggots and worms for fishing bait.
} 
Table 2

Amount of processed Category 3 raw material and products manufactured in the rendering industry from 2017-2020 (thousand tonnes).

\begin{tabular}{|c|c|c|c|c|}
\hline Description & 2017 & 2018 & 2019 & 2020 \\
\hline \multicolumn{5}{|c|}{ Category $3 \mathrm{ABPs}$} \\
\hline Raw material & $1,316.3$ & $1,372.6$ & $1,481.6$ & $1,572.9$ \\
\hline \multicolumn{5}{|c|}{ Products manufactured from Category $3 \mathrm{ABPs}$} \\
\hline PAP & 295.8 & 326.4 & 334.7 & 343.2 \\
\hline Fats & 177.3 & 187.1 & 203.5 & 223.7 \\
\hline
\end{tabular}

Source: authors' own study based on unpublished data from the Chief Veterinary Inspectorate.

In 2020, the distribution of PAP produced on the "basis" of processed Category $3 \mathrm{ABPs}$ (based on data from Chief Veterinary Inspectorate) was as follows:

A total of 373.9 thousand tonnes:

- exports to third countries -121.8 thousand tonnes,

- export to EU countries - 104.6 thousand tonnes,

- use in the production of petfood - 85.9 thousand tonnes,

- fish meal to produce feed for livestock - 7.4 thousand tonnes

- PAP other than fish meal to produce feed for aquatic animals 4.4 thousand tonnes,

- for fur animal farms - 3.9 thousand tonnes,

- other (including improvers, incineration) - 27.8 thousand tonnes,

- inventory -18.1 thousand tonnes.

In 2020, from the resources of 231 thousand tonnes of Category 3 fats more than $56 \%$ (less than 130 thousand tonnes) were used in plants manufacturing feed for livestock to produce feed for poultry, pigs, and ruminants. The given distribution figures for PAP and fats differ from the production figures in Table 2, as they do not consider changes in their stocks. The production of blood products is also an important element of ABPs processing, which, as one of the few sources of protein of animal origin, can currently be used in the feeding of livestock (pigs and poultry).

As can be seen from the above list, the largest item in the distribution of PAP is sales to foreign markets, mainly to third countries, where the feeding of livestock with processed animal proteins is not prohibited. Exporting these products is steadily growing, as shown in Figure 2. 


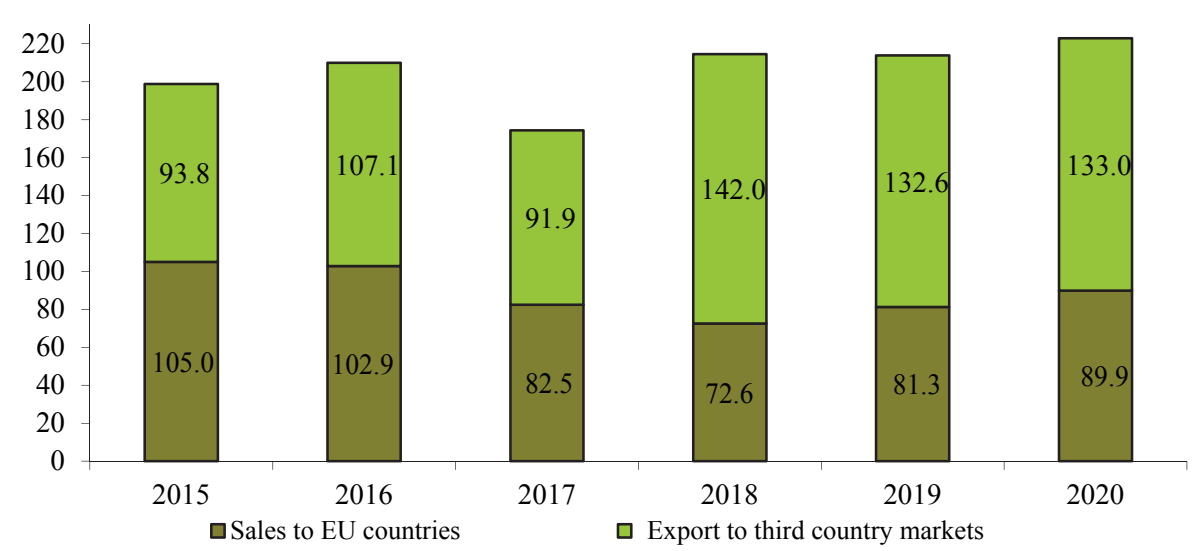

Fig. 2. Polish exports of processed animal protein from 2015-2020 (thousand tonnes). Source: authors' own study based on unpublished data from the Ministry of Finance.

However, the dynamics of exports is lower than that of production because of the growing internal demand reported by the dynamically developing sector producing petfood, the production of which in Poland increased from 2015-2020 as much as by approx. $78 \%$ (from 496 to approx. 880 thousand tonnes). The sector producing pet food uses PAP produced to a significant and increasing extent, and after the expected lifting of the ban on the use of processed protein, it will be a competition for potentially interested feed companies and animal breeders. In 2020, the domestic use of PAP in the pet food sector amounted to 85.9 thousand tonnes.

This type of high-protein raw material produced from ABPs has not been used in domestic trade for almost 20 years for the purpose of feeding livestock. Consequently, it is difficult to predict the market reaction and to what extent the processed animal proteins will be competitive with regard to the post-extraction soybean meal. However, one should consider the significant qualitative advantage of animal proteins over vegetable proteins. The amino acid composition of animal proteins is much closer to the nutritional needs of animals than soy protein. Moreover, the current technological trends go towards the processing of animal material by hydrolysis, so that the final product does not contain proteins, but single amino acids with a high degree of digestibility by animals (Burzyński, 2021). Considering the increasing dependence of the Polish feed industry and animal production on imported soybean meal and the possible administrative order to limit it, it can be assumed that processed animal protein will be of great interest to feed companies. Consequently, its prices are likely to be high, by a dozen or even several dozen percent above the level of imported GM soybean meal. Immediately before the introduction of the ban on the import of meat and bone meals, the level of prices was also clearly higher, as compared to other high-protein components (except fish meal), including soybean meal (Kisiel and Dzwonkowski, 2001). Nevertheless, processed animal protein may be competitive in terms of the unit price of protein, as compared to soybean meal, apart from the more favorable amino acid composition and its better digestibility. 


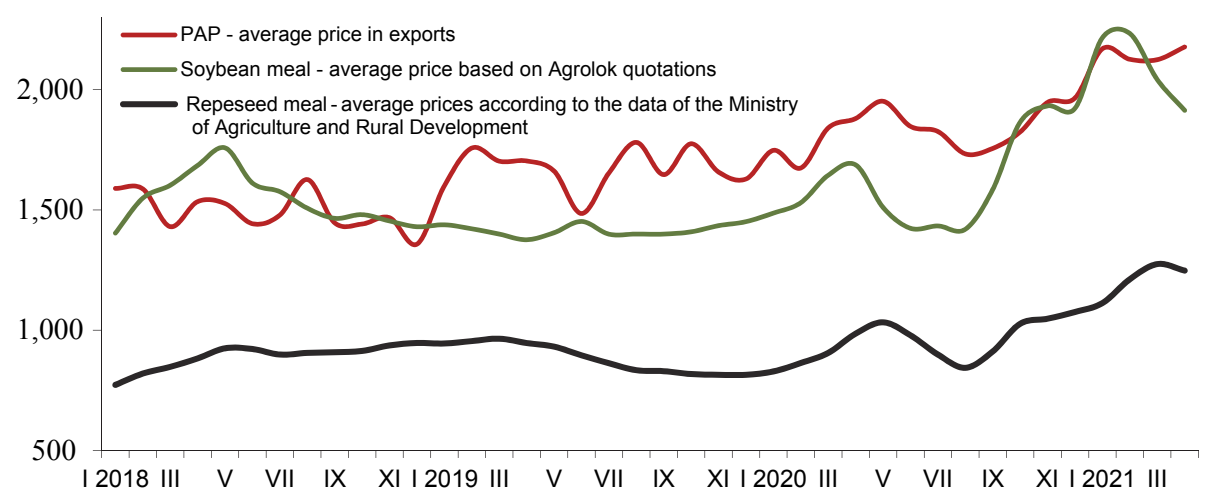

Fig. 3. PAP export prices compared to domestic oil meal prices (PLN/tonne).

Source: unpublished data from the Ministry of Finance, the Ministry of Agriculture and Rural Development Oil Plant Market newsletter, Agrolok stock exchange quotations.

From 2019-2020, the PAP export prices were on average by approx. 20\% higher than the prices of soybean meal and nearly twice as high as the price of rapeseed meal. In the second half of 2020, due to the turbulences caused by COVID-19 and other economic factors, prices of feed components, especially soybean meal, started to grow dynamically. As a result, at the turn of 2020 and 2021, soybean meal was even temporarily more expensive than PAP, but in the spring 2021 the price relations went back to the level before the turmoil. However, one should be aware of the fact that if rendering plants decide to produce PAP from poultry and pork in a very strict regime, then it will probably be associated with increased prices of such PAP. Currently, the principles of "species purity" do not have to be respected, and according to this principle the costs of production will probably be higher already at the stage of obtaining the raw material, and then its processing, storage, and transport. For a processing plant to decide on such a process, it will have to be convinced, and preferably certain, that it will find a buyer for PAP produced at higher costs, but also at a higher selling price.

Twenty years ago, animal meals constituted a significant part of the consumption structure of high-protein feed materials. In the 1999/2000 season, i.e., immediately before the introduction of the import ban, the consumption of meat and bone meal in Poland amounted to 454 thousand tonnes, of which 133 thousand tonnes were of domestic production and 321 thousand tonnes were imported (Table 3, Figure 4). 


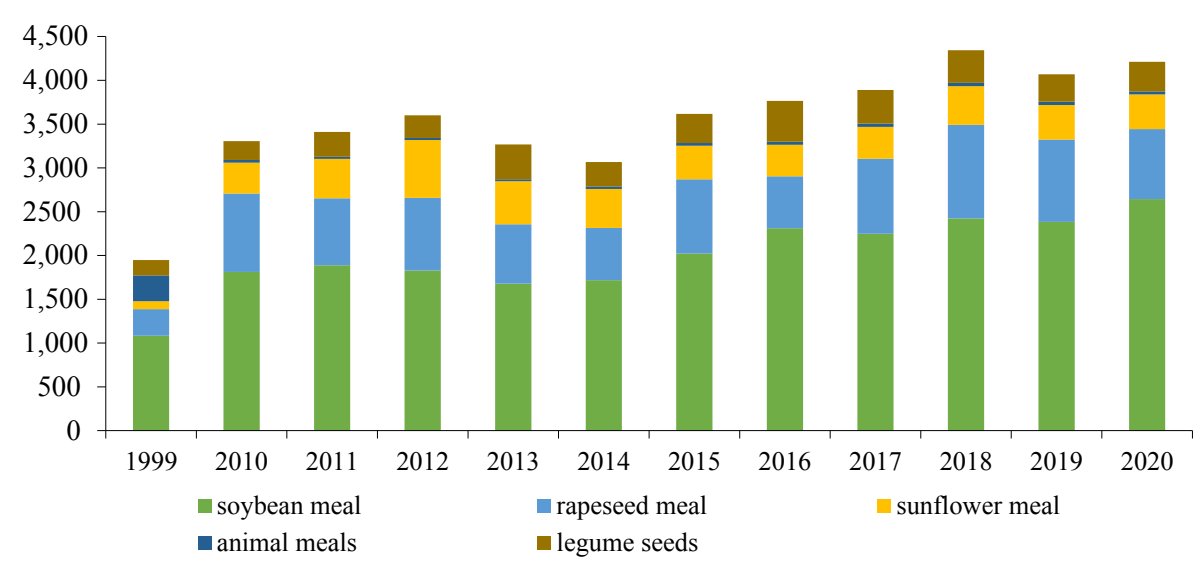

Fig. 4. Consumption of high-protein raw materials in Poland (PLN/tonne).

Source: Rynek pasz $(2001 ; 2020)$.

It accounted for $7.4 \%$ (domestic) and $17.9 \%$ (imported), respectively, in total more than $25 \%$ of the total resources of high-protein materials used in this period in Poland. In the protein equivalent, this share was even higher and amounted to almost $31 \%$. Soybean meal and, to a lesser extent, rapeseed meal were of the greatest importance in the structure of the resources, as at present(Table 3). The dynamically growing demand for high-quality feed used in the growing poultry production, but also in the rearing of pigs and cattle, resulted in an increased demand for high-protein feed materials, the consumption of which has increased by $132 \%$ in the last twenty years (from 1,794 to 4,165 thousand tonnes).

Having eliminated processed animal protein along with meat and bone meals, the demand for high-protein components to produce feed is satisfied practically only by raw materials of plant origin, mainly soybean meal, and to a lesser extent rapeseed and sunflower meals, and legume seeds (Hanczakowska and Księżak, 2012). The consumption of post-extraction soybean meal for several years has exceeded 2,500 thousand tonnes, in the case of rapeseed middling it is approaching 1000 thousand tonnes, and in the case of sunflower meal, it fluctuates in the range of 350-400 thousand tonnes (Dzwonkowski, 2016).

Despite many support measures and subsidies for cultivation, the production and consumption of legume seeds are relatively small and do not exceed 300 thousand tonnes (lupins, peas, horse beans), and after considering grain and legume mixtures, this amount increases by 100-150 thousand tonnes (Table 3, Figure 3). However, there are potential opportunities to increase the use of domestic plant protein sources, but due to nutritional limitations and the skeptical approach of animal breeders and feed producers, they are still of little yet growing importance in the protein feed balance (Dzwonkowski, 2018). According to the assessment of representatives of the feed industry, an important element limiting the use of domestic sources of protein is relatively high prices, as compared to imported GM soybean meal (Dzwonkowski, 
2020), even though the average level of their procurement prices recorded by Statistics Poland (GUS, 2021) in 2020 (PLN 1,023/t - peas, PLN 889/t - fodder peas, and PLN 997/t - lupins) was 35-40\% lower than the prices of post-extraction soybean meal. Moreover, their use is profitable in the case of small-scale commercial and organic farms (Kasprowicz-Potocka, Zaworska and Rutkowski, 2014, parts 1-2), and will not necessarily prove successful in intensive farming.

Table 3

Resources (consumption) of the main high-protein feed materials in Poland for livestock

\begin{tabular}{|c|c|c|c|c|c|}
\hline \multirow{3}{*}{ Description } & \multirow{2}{*}{$\begin{array}{l}\text { protein } \\
\text { content } \\
\%\end{array}$} & \multicolumn{2}{|c|}{$1999 / 2000$} & \multicolumn{2}{|c|}{$2020 / 2021 a$} \\
\hline & & $\begin{array}{l}\text { in product } \\
\text { weight }\end{array}$ & $\begin{array}{l}\text { in protein } \\
\text { equivalent }\end{array}$ & $\begin{array}{l}\text { in product } \\
\text { weight }\end{array}$ & $\begin{array}{l}\text { in protein } \\
\text { equivalent }\end{array}$ \\
\hline & \multicolumn{5}{|c|}{ in thousand tonnes } \\
\hline $\begin{array}{l}\text { domestic animal } \\
\text { meals }\end{array}$ & 55 & 133 & 73 & - & - \\
\hline $\begin{array}{l}\text { imported animal } \\
\text { meals }\end{array}$ & 55 & 321 & 177 & - & - \\
\hline post-extraction & 65 & 3 & 2 & 35 & 23 \\
\hline $\begin{array}{l}\text { fish meal } \\
\text { post-extraction }\end{array}$ & 45 & 981 & 441 & 2,504 & 1,127 \\
\hline $\begin{array}{l}\text { soybean meal } \\
\text { post-extraction }\end{array}$ & 37 & 18 & 7 & 368 & 136 \\
\hline $\begin{array}{l}\text { sunflower meal } \\
\text { rapeseed meal }\end{array}$ & 34 & 266 & 90 & 970 & 330 \\
\hline legume seeds ${ }^{\mathrm{b}}$ & 26 & 72 & 19 & 288 & 75 \\
\hline TOTAL & - & 1,794 & 809 & 4,165 & 1,691 \\
\hline & & & sumption stru & $(\%)$ & \\
\hline $\begin{array}{l}\text { domestic animal } \\
\text { meals }\end{array}$ & - & 7.4 & 9.0 & - & - \\
\hline $\begin{array}{l}\text { imported animal } \\
\text { meals }\end{array}$ & - & 17.9 & 21.8 & - & - \\
\hline post-extraction & - & 0.2 & 0.2 & 0.8 & 1.3 \\
\hline $\begin{array}{l}\text { nSh meal } \\
\text { post-extraction }\end{array}$ & - & 54.7 & 54.6 & 60.1 & 66.6 \\
\hline $\begin{array}{l}\text { soybean meal } \\
\text { post-extraction }\end{array}$ & - & 1.0 & 0.8 & 8.8 & 8.1 \\
\hline $\begin{array}{l}\text { sunflower meal } \\
\text { rapeseed meal }\end{array}$ & - & 14.8 & 11.2 & 23.3 & 19.5 \\
\hline legume seeds ${ }^{\mathrm{b}}$ & - & 4.0 & 2.3 & 6.9 & 4.4 \\
\hline TOTAL & - & 100.0 & 100.0 & 100.0 & 100.0 \\
\hline
\end{tabular}

${ }^{\mathrm{a}}$ estimate; ${ }^{\mathrm{b}}$ without grain and legume mixtures

Source: own calculations and estimates based on Rynek pasz $(2001 ; 2020)$. 
However, the feed industry may need to increase the consumption of domestic high-protein raw materials to reduce the share of imported GM feed materials (soybean meal). Although in November 2020, the amendment to the Act on Feed (Ustawa, 2020) extended the moratorium on the prohibition of the production, placing on the market and use of genetically modified feed and genetically modified organisms intended for feeding animals by another two years (until January 1, 2023), but its adoption raises a growing opposition among Members of Parliament and the public. Multifaceted activities undertaken for at least ten years (subsidies for the cultivation of protein crops, multi-year programs financed from the state budget, training, dissemination, and popularization activities, etc.), aimed at increasing the production and use of domestic sources of protein, and the reduction, and preferably the elimination of imported GM meal from the feeding of livestock, have not brought satisfactory results so far. The import and consumption of soybean meal are systematically growing. In the production and consumption of domestic high-protein crops, after a temporary increase, we have been regressing again for several years. In this situation, introducing an administrative order of partial substitution of GM feed materials and feeds with domestic protein sources is more and more seriously considered by using the so-called indicative targets of substitution, differentiated depending on the type of produced feed. Therefore, it can be assumed that the next extension of the possibility of using GMO feeds will depend on the adoption of indicative targets, assuming their gradual reduction due to the increase of domestic protein consumption. The pressure of consumers who want GMO-free food (Institute for Civic Affairs) may also be increasingly important.

In Poland, the share of feed for poultry, in particular for pigs produced without the use of genetically modified feed materials, labeled and sold as GMO-free, is very small. In 2019, the production of poultry feed in the feed companies covered by the survey amounted to 2,944 thousand tonnes, and labeled as GMO-free 12.5 thousand tonnes, which accounted for only $0.4 \%$ of the share. The importance and share of feed for pigs labeled as GMO-free was even less important, as their volume amounted to 1.2 thousand tonnes, with all their production at the level of 1,384 thousand tonnes, which was only $0.1 \%$. In 2020 , the shares increased only slightly. On the other hand, the share of feed for cattle labeled as GMO-free exceeded $90 \%$ (Dzwonkowski, 2020). The European Feed Manufacturers' Federation estimates the share of non-GMO feed in the structure of industrial feed production for poultry and pigs in Poland below 5\% (FEFAC, 2020). On the other hand, in Germany, non-GMO feeds for poultry constitute as much as $95 \%$, although their total production is only approx. 10\% lower than in Poland and in 2019 amounted to 6.4 million tonnes. In countries such as Sweden and Austria, feed for poultry is produced exclusively as non-GMO. This leads to the conclusion that even in the case of production on a larger scale, it is possible to stop using GMO raw materials, although it is presumably associated with higher costs. PAP may be one of the elements of the policy for replacing GMO raw materials (soybean meal) in feed. The profitability of such production will be finally accepted by the market and consumers. 


\section{Conclusions}

Allowing the use of processed animal protein in the feeding of livestock, in view of the growing real need to substitute imported GM soybean mean, is likely to cause interest in this extremely valuable high-protein material on the part of feed companies and livestock breeders. However, very strict regulations regarding the collection of raw material, its processing, and the production of PAP, and those at the stage of its use in the production of industrial feed may be a very important limitation. It will be a great challenge to maintain "species purity" in the production and cross-feeding process. Most of the feed factories in Poland are specialized in mixed production. Only a few will be able to afford to establish "pig" and "poultry" factories. Moreover, the feed industry and livestock breeders must compete with current recipients of processed animal protein, especially exporters and producers of the so-called petfood, as the volume of PAP produced so far attracts buyers by offering appealing prices from the point of view of the rendering industry. The fact that retail chains more and more often want to offer consumers meat from animals which were fed with vegetarian feed during its lifetime that was based solely on plant raw materials may also be a very important factor limiting the use of PAP.

With optimistic assumptions that the entire export volume of processed feed protein would remain on a domestic scale and would be used in the industrial production of feed for poultry and pigs, it would still account for just over 5\% (in protein equivalent around $6.5 \%$ ) in the balance of high-protein feed raw materials. Thus, it would only slightly reduce the import and consumption of GM soybean meal, but along with the promotion and activities aimed at developing the production and consumption of domestic plant-based feed protein sources, it would be consistent with the continuation of the policy of limiting the use of imported GM feed and improving protein self-sufficiency. 


\section{References}

Agrolok. Notowania cen śruty sojowej Hi-Pro. Retrieved from: https://www.agrolok.pl/notowania/notowania-sruty-sojowej.html (access date: 4.07.2021).

Buraczewska, L., Buraczewski, S. (2015). Żywienie zwierząt i paszoznawstwo. T. I. Warszawa: PWN.

Burzyński, R. (2021). Unieszkodliwianie padtych zwierzą i utylizacja. Przybliżamy nieznany przemyst. Retrieved from: https://agronews.com.pl/artykul/unieszkodliwianie-padlych-zwierzat-i-utylizacja-przyblizamy-nieznany-przemysl/ (access date: 1.03.2021).

Commission Regulation (EU) No 142/2011 of 25 February 2011 implementing Regulation (EC) No 1069/2009 of the European Parliament and of the Council laying down health rules as regards animal by-products and derived products not intended for human consumption and implementing Council Directive 97/78/EC as regards certain samples and items exempt from veterinary checks at the border under that Directive Text with EEA relevance.

Davison, J., Ammann, K. (2017). New GMO Regulations for Old: Determining a New Future for EU Crop Biotechnology. GM Crops Food, 8: 1, pp. 13-34.

Dzwonkowski, W. (2016). Analiza sytuacji na krajowym rynku pasz białkowych w kontekście ewentualnego zakazu stosowania materiałów paszowych GMO. Roczniki Naukowe SERiA, t. 18, z. 3, pp. $47-52$.

Dzwonkowski, W. (2018). Możliwości zwiększenia wykorzystania krajowych pasz białkowych w kontekście ewentualnego zakazu stosowania pasz GMO w produkcji zwierzęcej. Roczniki Naukowe SERiA, t. 20, z. 4, pp. 41-46.

Dzwonkowski, W. (2020). Ocena udziału w rynku pasz przemysłowych oznakowanych jako ,,wolne od GMO”. In: Ocena sytuacji na światowym i krajowym rynku roślin białkowych w aspekcie bilansu paszowego. Opracowanie dla MRiRW. Warszawa: IERiGŻ-PIB.

FEFAC: FEED and FOOD 2020. Retrieved from: https://fefac.eu/wp-content/uploads/2021/03/FF 2020_Final.pdf (access date: 30.06 .2021 ).

Gmplus.org. Possibility for Producers of Processed Animal Protein (PAP) Products to Get Gmp+ Certified. Retrieved from: https://www.gmpplus.org/en/publications/gmp-news/processed-animal-proteins (access date: 10.07.2021).

Grela, E.R., Czech, A. (2019). Pasze alternatywne w odniesieniu do soi genetycznie modyfikowanej w żywieniu zwierząt. Wiadomości Zootechniczne, R. LVII, 2, pp. 66-77.

Hanczakowska, E., Księżak, J. (2012): Krajowe źródła białkowych pasz roślinnych jako zamienniki śruty sojowej GMO w żywieniu świń. Roczniki Nauk Zootechnicznych, Vol. 39, Issue 2, pp. 171-187.

Instytut Spraw Obywatelskich. Retrieved from: https://instytutsprawobywatelskich.pl/czy-jestesmy-skazani-na-zywnosc-gmo/ (access date: 30.06.2021).

Kasprowicz-Potocka, M., Zaworska, A., Rutkowski, A. (2014). Krajowe źródła białka w żywieniu świń są opłacalne w gospodarstwach drobnotowarowych i ekologicznych. Cz. 1. Trzoda chlewna, 9/2014, pp. 36-39.

Kasprowicz-Potocka, M., Zaworska, A., Rutkowski, A. (2014). Krajowe źródła białka w żywieniu świń są opłacalne w gospodarstwach drobnotowarowych i ekologicznych. Cz. 2. Trzoda chlewna, 10/2014, pp. 46-48.

Kisiel, M., Dzwonkowski, W. (2001). Rola mączek mięsno-kostnych w bilansie białka paszowego w Polsce. Ekspertyza wykonana na zlecenie biura poselskiego H. Stokłosy. Warszawa.

MRiRW. Rynek Roślin Oleistych. Retrieved from: https://www.gov.pl/web/rolnictwo/rynek-roslin-oleistych-notowania-za-okres-21-27062021-r (access date: 04.07.2021). 
Mroczek, R., Dzwonkowski, W. (2021). Branża utylizacyjna w Polsce w latach 2017-2020. Warszawa: IERiGŻ-PIB.

Regulation (EC) No 999/2001 of the European Parliament and of the Council of 22 May 2001 laying down rules for the prevention, control and eradication of certain transmissible spongiform encephalopathies.

Regulation (EC) No 853/2004 of the European Parliament and of the Council of 29 April 2004 laying down specific hygiene rules for food of animal origin.

Regulation (EC) No 1069/2009 of the European Parliament and of the Council of 21 October 2009 laying down health rules as regards animal by-products and derived products not intended for human consumption and repealing Regulation (EC) No 1774/2002 (Animal by-products Regulation).

Rutkowski A. (ed.). (2021). Zwiększenie wykorzystania krajowego białka paszowego dla produkcji wysokiej jakości produktów zwierzęcych i w warunkach zrównoważonego rozwoju. Raport końcowy z realizacji Programu Wieloletniego 2016-2020. IUNG-PIB.

Rynek mięsa. Stan i perspektywy (2021). No. 60. Analizy Rynkowe. Warszawa: IERiGŻ-PIB.

Rynek pasz. Stan i perspektywy (2001). No. 10. Analizy Rynkowe. Warszawa: IERiGŻ-PIB, ARR, MRiRW.

Rynek pasz. Stan i perspektywy (2020). No. 42. Analizy Rynkowe. Warszawa: IERiGŻ-PIB.

Statistics Poland (2011-2020). Roczniki Statystyczne Rzeczpospolitej Polskiej 2011-2020. Warszawa: GUS.

Statistics Poland (2021). Skup i ceny produktów rolnych w 2020 roku. Retrieved from: https:// stat.gov.pl/obszary-tematyczne/rolnictwo-lesnictwo/rolnictwo/skup-i-ceny-produktow-rolnych-w-2020-roku,7,17.html (access date: 30.06.2021)

Ustawa z dnia 22 listopada 2013 r. o zmianie ustawy o ochronie zdrowia zwierząt oraz zwalczaniu chorób zakaźnych zwierząt oraz niektórych innych ustaw (Dz.U. 2014, poz. 29).

Ustawa z dnia 19 listopada 2020 r. o zmianie ustawy o paszach (Dz.U. 2020, poz. 2175).

Weiner, A., Paprocka, I., Gołębiowska, A., Kwiatek, K. (2016). Wykrywanie przetworzonego białka zwierzęcego w paszach - ocena wyników badań biegłości. Pasze Przemysłowe, Vol. 25, No. 3/4, pp. 80-86.

Weiner, A., Paprocka, I., Gołębiowska, A., Kwiatek, K. (2018). Zastosowanie metody real-time PCR do identyfikacji DNA przeżuwaczy w surowych produktach pochodzenia zwierzęcego. Medycyna Weterynaryjna, 74(4), 272-275.

Wojewódzki Inspektorat Weterynarii w Krakowie (b.d.). Retrieved from: http://www.wiw.krakow.pl/files/142_2011.pdf (access date: 05.07.2021). 


\title{
PRZETWORZONE BIAŁKO ZWIERZECEE JAKO JEDEN Z ELEMENTÓW POLITYKI OGRANICZANIA GMO W ŻYWIENIU ZWIERZĄT GOSPODARSKICH
}

\begin{abstract}
Abstrakt
Celem niniejszego artykułu jest przedstawienie różnych uwarunkowań i aspektów wykorzystania przetworzonego biatka zwierzecego (PAP, ang. processed animal protein) $w$ żywieniu zwierzat gospodarskich, $w$ perspektywie zniesienia $d w u d z i e s t o l e t n i e g o$ zakazu jego stosowania $w$ paszach oraz określenia jego roli w polityce ograniczania GMO. Przeprowadzono analize aktualnego stanu prawnego oraz nowych uwarunkowań $i$ wymagań na każdym etapie produkcji, a także zagospodarowania przetworzonego biatka zwierzęcego, wykorzystując stosowne polskie i unijne akty prawne. Określono skalę produkcji i kierunki dotychczasowego zagospodarowania przetworzonego biatka zwierzęcego oraz uwarunkowania cenowe potencjalnego jego wykorzystania w produkcji pasz. W analizie zjawiska, oprócz literatury przedmiotu, korzystano przede wszystkim z danych źródłowych Głównego Inspektoratu Weterynarii (GIW) oraz GUS i Ministerstwa Finansów.

Przeprowadzona analiza uwarunkowań organizacyjno-produkcyjnych doprowadziła do konkluzji, że głównym problemem może być zachowanie tzw. czystości gatunkowej w procesie produkcji przetworzonego białka zwierzęcego i pasz z jego wykorzystaniem, a nastęnie krzyżowe skarmianie (drobiowe dla trzody i trzodowe dla drobiu), oraz rygorystyczne konsekwencje w przypadku wykrycia nieprawidłowości. Ponadto czynnikiem ograniczajacym może być jego wysoka cena $w$ relacji do innych pasz biatkowych oraz oczekiwania konsumentów, że oferowane do sprzedaży produkty zwierzęce zostaty wytworzone bez udziatu pasz pochodzenia zwierzecego. Rola i znaczenie dopuszczonego do skarmiania przetworzonego białka zwierzęcego w bilansie wysokobiałkowych surowców paszowych przypuszczalnie będa niewielkie, jednak należy popierać $i$ wykorzystywać każda możliwość korzystania z krajowych źródet biatka na rzecz ograniczenia stosowania importowanych pasz GM i poprawy samowystarczalności białkowej. Większa skalę krajowego wykorzystania tego bardzo wartościowego źródła biatka moga jednak wymóc działania administracyjne poprzez wprowadzenie wskaźnikowych celów substytucji importowanych pasz GM krajowymi źródłami białka.
\end{abstract}

Słowa kluczowe: substytucja, przetworzone białko zwierzęce, pasze GMO, skarmianie krzyżowe.

Submission date: 13.07.2021.

Final revision date: 6.09.2021.

Acceptance date: 1.10.2021.

O ile nie jest to stwierdzone inaczej, wszystkie materiały na stronie są dostępne na licencji Creative Commons Uznanie Autorstwa 4.0 Międzynarodowe.

Pewne prawa zastrzeżone na rzecz Instytutu Ekonomiki Rolnictwa i Gospodarki Żywnościowej - PIB.

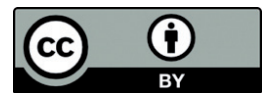

